THE SIX-DAY WAR 


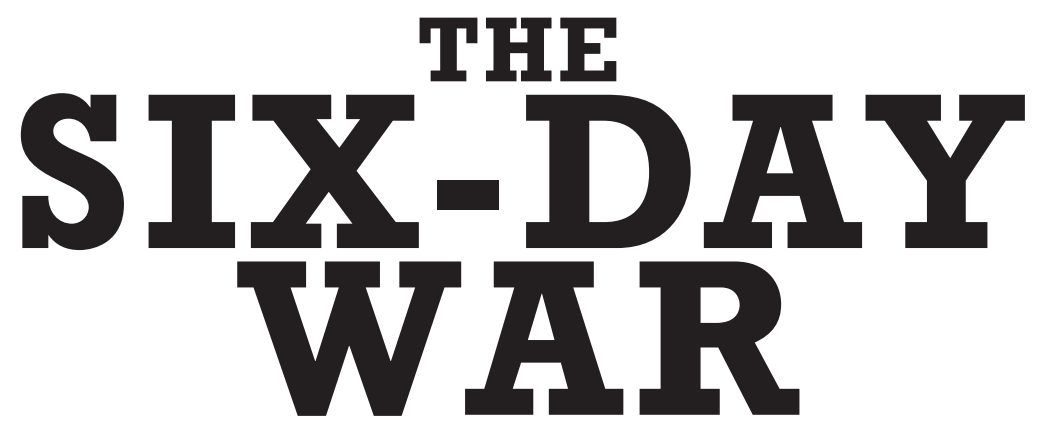

THE BREAKING OF THE MIDDLE EAST

\section{GUY LARON}

YALE UNIVERSITY PRESS

NEW HAVEN AND LONDON 
Copyright (C) 2017 Guy Laron

All rights reserved. This book may not be reproduced in whole or in part, in any form (beyond that copying permitted by Sections 107 and 108 of the U.S. Copyright Law and except by reviewers for the public press) without written permission from the publishers.

For information about this and other Yale University Press publications, please contact:

U.S.Office: sales.press@yale.edu yalebooks.com

Europe Office: sales@yaleup.co.uk yalebooks.co.uk

Typeset in Minion Pro by IDSUK (DataConnection) Ltd

Printed in Great Britain by Gomer Press, Llandysul, Ceredigion, Wales

Library of Congress Control Number: 2016957143

ISBN 978-0-300-22270-8

A catalogue record for this book is available from the British Library.

10987654321

iv 